\title{
LOCAL SELFGOVERNMENT LEADERS' INVOLVEMENT OF THE RESIDENTS TO PARTICIPATION AND ESTABLISHMENT OF COMMUNICATION IN THE COMMUNITY
}

УДК 316.46:316.472.4:352.075.1(477.7) DOI https://doi.org/10.32843/26635208.2020.16.4

\section{Бойко Г.В.}

к.психол.н., доцент,

доцент кафедри соціальної філософії та управління

Запорізький національний університет

Кулик М.A.

к.соціол.н., доцент касредри соціології Запорізький національний університет
У статті розглядаються особливості залучення лідерами органів самоорганізації населення (ОСН) до участі мешканців територіальної громади в розбудові території. Аналізується теоретичний $і$ практичний здобуток уцьому проблемному полі науковців сорер державного управління, соціології, психології та права. Авторами статті проведено соціологічне опитування серед лідерів ОСН м. Запоріжжя та м. Маріуполя. Результати опитування дали змогу виявити як підгрунтя для розвитку довіри в громаді, так й обмеження в комунікації між лідерами ОСН і мешканиями. Автори звертають увагу на таке підгрунтя для розвитку комунікації між лідерами ОСН і мешканиями, як особиста зацікавленість лідерів ОСН у розбудові території, термін проживання лідера $\mathrm{OCH}$ на території, джерело ініціативи обрання голови ОСН, рівень довіри лідерів ОСН до мешканців територіальної громади, ступінь залученості мешканців до активної роботи в громаді й оцінювання участі членів громади в розбудові території проживання. Для подолання виявлених обмежень, розвитку практик залучення, комунікативних і лідерських навичок для голів та активістів громад розроблено тренінгову програму. Ця програма базується на використанні положень короткотермінової терапії, орієнтованої на вирішення (BSFT), і включає вправи, спрямовані на встановлення й розвиток взаємин довіри лідерів щодо представників територіальної громади; мотивування членів громади до спільних дій; фрормування та розвиток у лідерів практичних навичок профрілактики й есрективного розв'язання конфрліктних ситуацій у громаді. Обговорюється досвід упровадження тренінгових програм у громадах м. Запоріжжя та м. Маріуполя.

Ключові слова: територіальна громада, лідери територіальної громади, місцеве самоврядування, залучення мешканців, треніне розвитку лідерських і комунікативних навичок.
The article deals with the peculiarities of local selfgovernment leaders' involvement of territorial community's residents to the participation for development of the territory. Theoretical and practical achievements of this problem in the scientific area of public administration, sociology, psychology and law are analyzed. The authors of this article conducted the sociological survey of the local selfgovernment' leaders in Zaporizhia and Mariupol. The results of the survey allowed to reveal basis for development of trust in the community and limitations in the communication between local selfgoverment's leaders and the residents. The authors draw attention to the such development basics of communication between LS leaders and the residents as: leaders' personal interest in the development of the territory, the period of leader' residence, the source of the initiative of the Head of local selfgovernment's elect, the level of leaders' trust to the territorial community, the degree of residents' involvement in the active work at the community and the leaders' evaluation of the participation of community members in the development of the territory. A training program was developed for Heads and community activists for overcome the identified limitations, develop the involvement practices, communication and leadership skills. This program is based on the provisions of the Brief Solution Focussed Therapy (BSFT) and includes exercises aimed at: establishing and developing of the trust relationship between the leaders and the residents of the local community; motivating community members to the joint action; formation and development of leaders' skills in the prevention and effective resolution in conflict situations. It is discussed in the article the experience of implementing training programs in the communities of Zaporizhzhya and Mariupol.

Key words: territorial community, leaders of the territorial community, local selfgovernment, involvement of the residents, the development of leadership and communication skills training.
Постановка проблеми. Вирішення завдань розвитку Української держави потребує вирішення питань формування та розвитку громадянського суспільства. Один із важливих напрямів їх розв'язання пов'язаний із формуванням та активізацією місцевих громад. Саме через цей інститут реалізується багато завдань із децентралізації влади й долучення громадян до реальної участі в прийнятті важливих рішень, що дійсно визначають реальні позитивні зміни, яких так потребує україн- ське суспільство. У контексті досягнення поставлених завдань значущості набувають дослідження практик залучення до участі, які застосовують лідери територіальних громад у взаємодії з мешканцями, і розвитку їхніх навичок налагодження комунікації в громаді через використання групового тренінгу. Такі дослідження дають можливість обґрунтувати та застосувати прикладні методи й техніки, що сприяють залученню до участі й налагодження комунікації в громаді. 
Аналіз останніх досліджень і публікацій. Реалізація політики децентралізації в Україні пов'язана з розбудовою об'єднаних територіальних громад (далі - ОТГ), повноваження яких є досить широкими в юридичному та економічному плані [10]. Щодо міського сектора, стратегія децентралізації реалізується в створенні об'єднань будинкових, вуличних і квартальних комітетів, правове поле функціонування яких регламентується Законом України «Про органи самоорганізації населення» [11]. у Донецькій області (а саме м. Маріуполі в межах нашого дослідження) органи самоорганізації населення (далі - ОСН) мають свою специфіку й назву: Комітети самоорганізації населення (далі - КСН). Керівні повноваження $\mathrm{OCH}(\mathrm{KCH})$ належать голові $\mathrm{OCH}$, що виконує функції лідера, а саме визначає стратегію та організовує діяльність органів самоорганізації та громади загалом.

Проблематика формування й розвитку місцевих або територіальних громад зараз перебуває у фокусі міждисциплінарних досліджень соціологів, психологів, політологів і дослідників сфери державного управління. Розкриттю теоретичного та практичного змісту поняття «територіальна громада» присвячені роботи В. Березинського [3], О. Мороз [8], О. Батанова [2], В. Кирилюк [5] та інших. Окремі аспекти й особливості практичної розбудови територіальних громад досліджували М. Бриль, О. Врублевський, О. Данчева [12] та інші. Реалізація політики децентралізації зумовила необхідність прикладних досліджень динаміки процесу формування й розвитку територіальних громад. Київським міжнародним інститутом соціології реалізовано чотири хвилі Всеукраїнського соціологічного дослідження громадської думки щодо питань децентралізації (остання хвиля проводилася в листопаді-грудні 2018 року) [6]. Комплексне дослідження серед представників влади й населення новостворених територіальних громад «Особливості впровадження реформи децентралізації в Запорізькій області» реалізоване за ініціативою Запорізького ВПУ «Центр розвитку місцевого самоврядування» [9]. Кількісне дослідження «Реформи в Україні: зміни на краще або імітація прогресу» проведено Інститутом Горшеніна спільно з Представництвом Фонду ім. Фрідріха Еберта в Україні у 2019 році [4]. Отже, з огляду на потребу діагностики стану реалізації політики децентралізації в Україні, проблематика правового поля, організації, економічної ефективності територіальних громад широко досліджується на міждисциплінарному рівні. Однак подальших досліджень потребує саме діяльність органів самоорганізації населення та робота з їх керівним складом щодо залучення мешканців територі- альної громади до активної розбудови вулиць і кварталів міст.

Постановка завдання. Метою статті $€$ аналіз результатів соціологічного дослідження особливостей комунікації лідерів ОСН м. Запоріжжя та м. Маріуполя з мешканцями громади, обґрунтування й апробація тренінгової програми з розвитку лідерських і комунікативних якостей, які дають лідерам змогу ефективно комунікувати з мешканцями та залучати мешканців вуличних, квартальних і будинкових комітетів до участі в розвитку громади.

Виклад основного матеріалу дослідження. 3 метою дослідження особливостей реалізації лідерами ОСН практик залучення до участі представників громади авторами проведено соціологічне дослідження в межах проекту «Згуртуй громаду», що реалізовувався Запорізьким науковим товариством ім. Я. Новицького в рамках Української ініціативи з підвищення впевненості (UCBI) за фінансової підтримки Агентства США з міжнародного розвитку (USAID). Дослідження проводилося шляхом формалізованого групового очного письмового анкетування голів квартальних/будинкових/вуличних комітетів м. Запоріжжя та м. Маріуполя в січні-березні 2017 року. Загалом у дослідженні взяли участь 77 голів органів самоорганізації населення, серед яких 52\% - представники м. Запоріжжя, 48\% м. Маріуполя.

Для визначення практик залучення до участі й особливостей комунікації з членами громад важливим є дослідження особистої зацікавленості голів ОСН у розбудові території. У цьому контексті важливим є той факт, що голови ОСН $€$ представниками територіально укорінених груп, оскільки більшість (84\%) із них проживає на території власного комітету більше ніж 10 років. Це може свідчити про досить повне розуміння головами ОСН проблем будинку, вулиці чи кварталу, ОСН якого вони взялися очолювати. Щодо планів на майбутнє нинішніх голів ОСН, то зазначимо вкрай оптимістичну перспективу: 93,2\% з опитаних планують проживати на території власного комітету й у майбутньому. Це вказує на бажання респондентів проживати й працювати в цій громаді.

Процедура обрання голови ОСН, відповідно до Закону України «Про органи самоорганізації населення», передбачає проведення очного голосування серед мешканців територіальної громади. Особливо важливими в цьому контексті, на думку дослідницької групи, є отримані дані щодо суб'єктів ініціативи у висуненні нинішніх голів на їхню посаду, оскільки, коли мова йде про ініціативу висунення кандидата, ми можемо говорити про об'єктивний рівень довіри громади. Найактивнішими ініціаторами обрання мешканця на посаду голови OCH є громада (87\%). Це свідчить про сприй- 
няття головами ОСН себе як осіб із високим рівнем довіри мешканців. Власну ініціативу в обійманні посади голови ОСН відзначили ще 7,8\% (вони самі або ж їхня родина). І 5,2\% відзначили, що зайняли свої посади виходячи з ініціативи депутатів міської ради та районної адміністрації. Остання група голів $є$ лише в м. Маріуполі пропорційно по всіх районах, що може свідчити про особливості діяльності там $\mathrm{OCH}$, а саме утворення комітетів самоорганізації населення.

Задля розуміння характеру відносин, що вибудувалися в голів $\mathrm{OCH}$ із представниками владних структур, квартальним комітетом $\mathrm{OCH}$, мешканцями території $\mathrm{OCH}$, депутатами, спонсорами, ЗМІ, всеукраїнськими та міжнародними грантовими програмами, нами визначено рівень контактності із цими групами й з'ясовано рівень довіри голів ОСН до означених груп. За отриманими даними, визначено, що найнижчий рівень контактності голови ОСН мають у взаємодії зі ЗМІ, спонсорами, міжнародними та всеукраїнським грантовими програмами (лише третина опитаних включила їх у можливе коло своїх контактів). ЗМІ мають також найнижчий рівень довіри з усіх запропонованих для оцінки груп (3,17 бала з 5 можливих).

Особливу увагу в контексті поставленої мети публікації має отриманий факт про визначення учасниками опитування ступеня довіри до мешканців вуличних, квартальних і будинкових комітетів. Саме тому до інструментарію дослідження включено питання «Наскільки, на Вашу думку, можна довірити переліченим особам та організаціям вирішення питань щодо покращення умов проживання на територіях, що підпорядковані Вашому комітету?» (ступінь довіри респонденту запропоновано оцінити за 5-бальною шкалою, де 1 - зовсім не можна довіряти, 5 можна повністю довіряти). Відповідаючи на це запитання анкети, голови продемонстрували найбільший рівень довіри собі та своїй родині, що вказує на те, що власна родина $€$ джерелом підтримки для лідера $(4,78$ бала з 5 можливих), і маркує для дослідників ступень значущості показників довіри іншим визначеним групам. Так, наступними за рівнем довіри виступають представники квартального комітету, які отримали показник 4,48 бала, що дає нам можливість стверджувати, що квартальний комітет Голови сприймають як власну команду однодумців. Показовою $є$ наявність таких груп довіри, які в своєрідний спосіб розривають логіку розгортання кіл соціальної дистанції в територіальній громаді. Це є місцеві органи влади й депутати міської ради, рівень довіри до яких відзначений, відповідно, 4,12 та 3,9 бала. Ці отримані показники відповідають покаж- чику 4 (довіряю групі) шкали соціальної дистанційованості. Звертає на себе увагу порівняно $з$ попередніми показниками нижчий рівень довіри голів ОСН до своїх сусідів (який отримав показник 3,73 бала) і загалом до мешканців комітету (3,55 бала), що відображає визначене за результатами опитування зниження довіри до представників своєї громади за шкалою з тенденцією до наближення до «не довіряю». Як ми можемо бачити на рис. 1, довіра до мешканців вуличного/ будинкового/квартального комітету $\epsilon$ на порядок нижчою, ніж до депутатів, місцевих органів влади та квартального комітету.

Серед важливіших функцій голів, які очолюють органи самоорганізації населення, $€$, беззаперечно, одна найважливіша - організація мешканців комітету до спільної дії. Саме вміння голови ОСН порозумітися, знайти спільні точки зору та залучити мешканців $€$ основою для реалізації спільних завдань із розбудови території громади.

Як ми можемо бачити на рис. 2, за результатами опитування голів $\mathrm{OCH}$, до активної участі в роботі органів самоорганізації населення задіяна в більшості випадків $(59,7 \%)$ нечисленна група мешканців. Набагато більше ніж половина та всі мешканці задіяні лише в 9,1\% випадків.

Поступове об'єднання зусиль громади має свої важливі переваги: якщо мешканці бачать результати колективних зусиль, у яких вони беруть участь, і мають доволі чіткий план дій, поступово формується їхня особиста відповідальність і, відповідно, готовність до активної участі.

У контексті вищевикладеного набуває актуальності питання щодо залучення головами ОСН мешканців до спільної дії. Відповідно, в інструментарій дослідження включено питання «Чи можна покращити умови проживання на Вашій вулиці без участі її мешканців?», відповіді на яке дали змогу визначити зворотні стратегії голів ОСН щодо спрямовання мешканців до спільної дії. Результати дослідження показали, що більшість $(59,3 \%)$ голів ОСН усе ж таки впевнені, що без участі мешканців робота комітету щодо вирішення питань благоустрою не буде дієвою. Однак досить значна частина $(38,1 \%)$ голів ОСН відзначає, що ефективна робота комітету без участі мешканців можлива. Стратегія останньої визначеної групи навряд чи сприятиме об'єднанню мешканців комітету й залученню їх до спільних дій.

Відповідь на питання щодо причин уникнення голів $\mathrm{OCH}$ пошуку активної співпраці 3 мешканцями ми знаходимо в показнику рівня довіри. Аналізуючи відповіді на запитання анкети «Наскільки, на Вашу думку, можна довірити мешканцям вирішення питань 


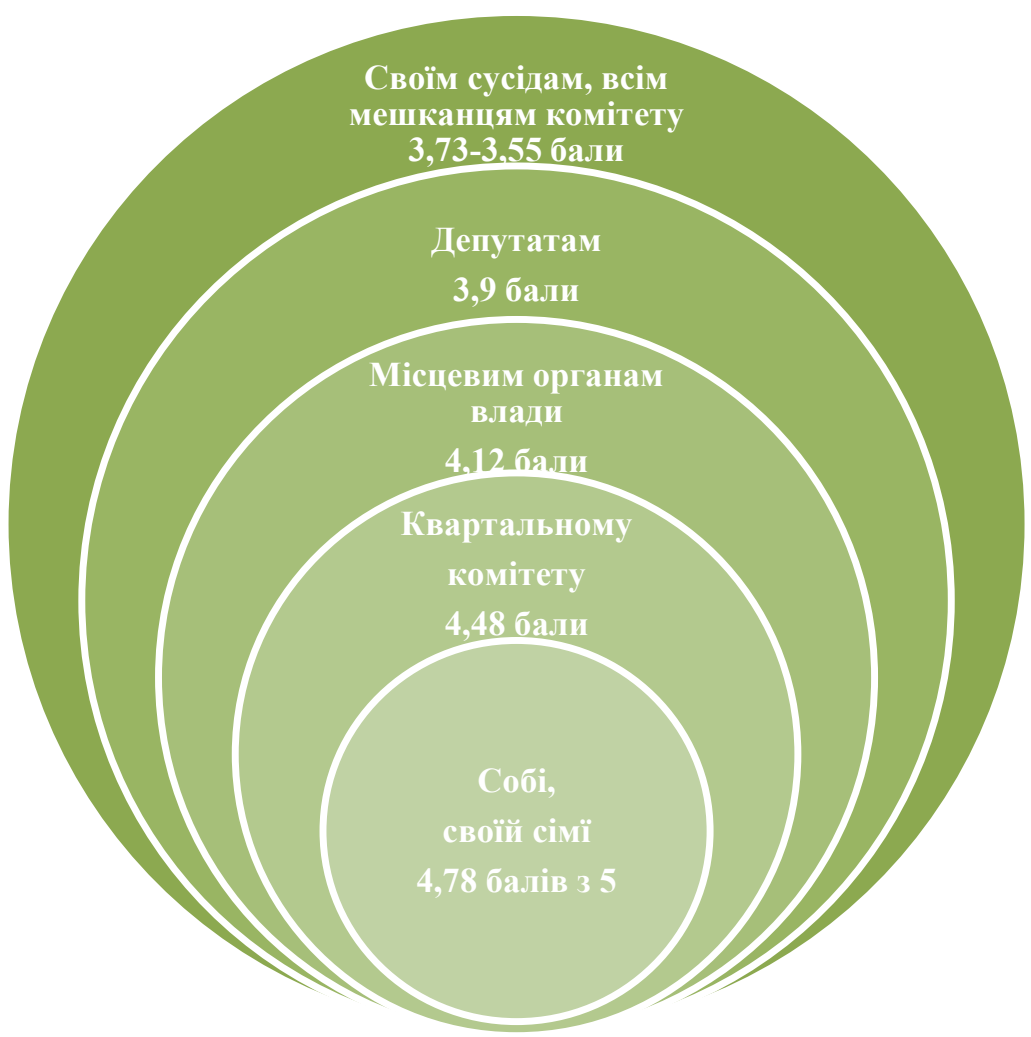

Рис. 1. Кола довіри голів ОСН до різних соціальних груп

Дані наведені в середніх оцінках, де 5 - найвищий рівень довіри

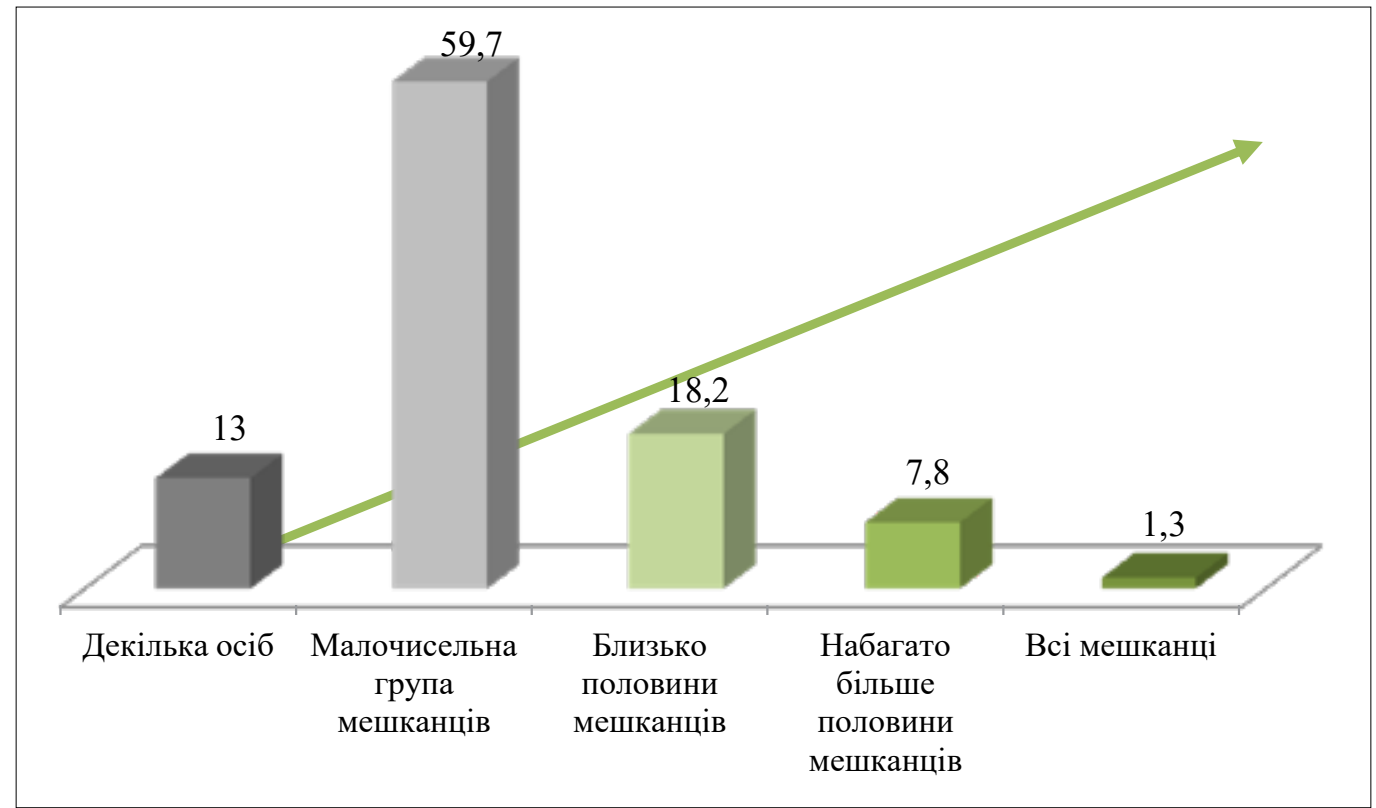

Рис. 2. Залученість мешканців території комітету до активної роботи з ОСН

Дані наведені у\%

щодо покращення умов проживання на територіях, що підпорядковані Вашому комітету?», доходимо висновку, що саме ті голови ОСН, які вбачають можливим покращення умов про- живання без участі мешканців, більшою мірою схильні не довіряти їм.

Відповідно до результатів проведеного дослідження, потребують вирішення питання 
налагодження спілкування в громадах, взаємної довіри між головами громад і мешканцями, розвиток мотивації членів громади на вирішення питань розвитку громади та реалізацію таких ініціатив, подолання опору та залучення до участі пасивних членів громади. Велике значення в керівництві в громаді мають лідерські вміння та навички голови (громади, квартального комітету, ОСББ, КСН), які сприяють налагодженню спілкування в громадах.

Для вирішення такихпитань уважаємо ефективним застосування тренінгів, що спрямовані не тільки на передачу інформації від керівника до учасників, а й на створення можливостей з обміну досвідом між головами громад. Обмін досвідом $є$ дуже важливим, адже серед учасників можуть бути люди з досвідом управління в громадах, але в інших умовах, коли на громади не покладалася настільки серйозна громадська, правова й економічна відповідальність. Тренінг створює умови для навчання, активного обміну досвідом, оновлення (перезавантаження) та розширення того досвіду учасників, який уже накопичений. У програму такого тренінгу мають бути включені вправи, спрямовані на розвиток комунікативних навичок щодо встановлення й розвитку контактів, запобігання проблемним ситуаціям та ефективного спілкування в проблемних ситуаціях; пошуку ресурсів для вирішення проблемних ситуацій і спілкування в такий спосіб, щоб це вирішення не тільки розв'язувало проблему, а й сприяло розвитку стосунків.

Нижче наведено кілька вправ, застосованих у тренінгах, що обговорюються як ілюстрації.

Вправа «Комплімент для розбудови взаємин і реалізації лідерства».

Вправа спрямована на розвиток умінь учасників розбудовувати стосунки в громаді загалом, сприяти розвитку мотивації членів громади на участь у спільних справах і проектах.

Перед виконанням вправи учасникам пропонуються для обговорення правила застосування компліменту, які розроблені в межах короткотермінової терапії, орієнтованої на вирішення (BSFT, Стів де Шазер, Інсу Кім Берг, США) [1]. Під компліментом розуміється висловлення, дія або емоційна реакція, що виражає повагу, захоплення чи заохочення. Нижче наведено основні правила ефективного компліменту: 1) Будьте точними, хваліть за конкретні справи; 2) «Хваліть за красу мудрих і красивих за мудрість», тобто компліментом пропонуйте напрям для розвитку; 3) Говоріть приємне іншим людям, коли Вам дійсно щось у них подобається! Якщо комплімент неправдивий - це лестощі, які повернуться проти Вас; 4) Ніколи не говоріть: «Ти виглядаєш краще, ніж я очікувала». Не дайте здогадатися людині, що Ви думали про неї гірше, ніж є насправді. 5) Реалізуючи комплімент, не говоріть про майбутнє, говоріть про те, ще є вже зараз. Після обговорення і тлумачення правил пропонується інструкція для виконання вправи.

Інструкція. Учасникам пропонується розділитися по групах (5-6 осіб), із них 5 (4) осіб сідають півколом, а один учасник - у центрі цього півкола, спиною до інших. Завдання для тих, що сидять півколом: говорити компліменти по черзі тому учаснику, який сидить попереду на стільці й розвернутий до них спиною. Той, хто слухає компліменти, має не перебивати й ні в який спосіб не коментувати те, що він чує. Після того, як усі сказали компліменти одному учаснику, реалізується правило «каруселі»: той, хто слухав компліменти, приєднується до півкола, а ті, хто знаходяться в півколі, посуваються, один учасник із півкола сідає в центр. Перед виконанням учасникам пропонується під час виконання вправи слідкувати за своїми враженнями та відчуттями.

Після виконання вправи учасникам пропонується поділитися своїми досвідом участі у виконанні вправи: 1) які їхні враження від слухання й надавання компліментів, що було приємнішим, легшим для застосування; 2) які 3 компліментів були найприємнішими, найбільше запам'яталися.

Обговорення здійснюється в загальному колі. У процесі обговорення важливо звернути увагу учасників на значущість компліментів для мотивації іншої людини, важливість невербальної взаємодії в процесі їх надання, ефективність застосування правил ефективного компліменту. Зазвичай виконання вправи викликає багато позитивних вражень в учасників і додатково сприяє розвитку міжособистісних контактів між учасниками.

Вправа «Лідерство в проблемних ситуаціях». Виконання вправи базується на застосуванні як методичного матеріалу модифікації стимульного матеріалу до тестів толерантності до фрустрації С. Розенцвейга (The Rosenzweig Picture-Frustration Study, PF study) [7]. Усі учасникам отримують по 3 картки, з якими вони мають попрацювати за інструкцією.

Інструкція. На кожній картці зображена взаємодія двох людей. Одна людина говорить іншій фразу, яка зазначена на картці. Дайте відповідь за людину, якій адресоване звернення, і запишіть її в блокнотах. Перша реакція, яка спала Вам на думку, є найкращою. Попрацюйте в такий спосіб із трьома картками.

Після завершення роботи 3 картками їі результати аналізуються на підставі застосування варіантів реакцій людей у проблемних ситуаціях, що обґрунтовані С. Розенцвейгом. Важливо пояснити варіанти спрямування реакцій і допомогти учасникам зіставити їх зі спрямуванням (на себе, на інших, ігнорування або намагання «зам'яти» ситуацію) та пошуком можливості емоційного відреагування 
(що сталося?), пошуку відповідального (хто винний?) або дій, спрямованих на вирішення проблеми (що робити?). Важливо відзначити найбільш конструктивне реагування, яке передбачає пошук відповіді на питання (що робити?) і поєднання зусиль власних та іншого учасника ситуації. Ефективне лідерство в проблемній ситуації має бути спрямоване на вирішення проблем і сприяння співробітництву з партнером. У такому разі воно передбачає насамперед уміння пропонувати власні дії, спрямовані на вирішення проблемної ситуації та надавати пропозиції конструктивних дій партнеру по взаємодії: «Я зроблю (пропозиція власних дій) ...; Вас прошу зробити ... (пропозиція діяти іншому в певний спосіб)».

У такий спосіб у процесі роботи учасники розвивають навички продуктивного встановлення й розвитку контактів із членами громади, розвинуть навички розв'язання конфліктних і напружених ситуацій, спілкування з «тяжкими» людьми, спрямування проблемного спілкування в конструктивне русло. Тренінг розвиває в учасників уміння користуватися прийомами психологічної самодопомоги, спрямованими на профілактику емоційного вигорання, пов'язаного з відчуттям низької продуктивності власних дій, недостатньої результативності зусиль і слабкої підтримки громади.

Досвід упровадження таких тренінгів на практиці, який реалізований у межах проектів, підтриманих ЄСПРОООН «Місцевий розвиток, орієнтований на громаду», USAID («Історичні локації», «Згуртуй громаду»), засвідчив таке. По-перше, на етапах презентації проектів для активістів громад,- учасники засвідчили свою зацікавленість і готовність узяти участь у такого роду тренінгах. Про необхідність організації таких тренінгів у межах програм заявила більше ніж половина учасників. По-друге, на етапі реалізації досить часто тренінгове заняття в новій групі починалося з деякого опору учасників. У таких випадках ефективною виявилася готовність керівника тренінгу врахувати актуальні побажання учасників щодо змісту тренінгових занять, наполегливість у необхідності всім учасникам брати участь і давати зворотній зв'язок. По-третє, на етапі активної роботи групи більшість учасників виявила задоволення власною участю, готовність ділитися досвідом і відкрито обговорювати ті проблеми, які виникають у взаємодії з представниками своєї громади, виносити та відкрито обговорювати питання, що хвилюють кожного. По-четверте, під час підведення підсумків і надання зворотного зв'язку щодо тренінгу учасники відзначили: 1) корисність обміну досвідом між учасниками, набуття нових навичок щодо спілкування з проблемними членами громади, а саме вирішення конфліктних ситуацій як у громаді, так і в спілкуванні з представниками владних структур; 2) налагодження готовності учасників тренінгу до власної ефективної взаємодії з активістами громади; 3) розвиток уміння зберігати конструктивне налаштування в проблемних ситуаціях, напрацювання ідей і конкретних прийомів щодо мотивування пасивних членів громади.

Висновки з проведеного дослідження. Проведене соціологічне опитування лідерів та активістів ОСН м. Запоріжжя та м. Маріуполя щодо їхніх практик залучення населення до активної участі дало можливість виявити ресурси в особистій зацікавленості лідерів $\mathrm{OCH}$ в активній розбудові території комітету й обранні їх саме з ініціативи мешканців. Натомість факторами обмежень у налагодженні комунікації між лідерами ОСН і представниками територіальної громади $€$ досить низький рівень довіри перших до других. Лідери $\mathrm{OCH}$ також відзначили залученість до активної роботи з ОСН лише нечисленної групи мешканців, і більше ніж половина опитаних визначила такий стан речей як критичний, оскільки вважає, що неможливо покращити умови проживання в їхніх комітетах без участі населення. Ці результати соціологічного дослідження довели необхідність розвитку лідерських якостей і навичок громади щодо залучення мешканців до участі. Застосування групового тренінгу для розвитку комунікативних і лідерських навичок голів ОСН продемонструвало ефективність застосування такої форми роботи через створення ситуації обміну досвідом вирішення схожих проблем, розвитку вміння ефективної взаємодії та залучення членів громади до спільних дій, профілактики й вирішення конфліктних ситуацій у спілкуванні з членами громади, сприяння розвитку вміння мотивувати членів громади до участі у вирішенні завдань громади.

\section{ЛITEPATУPA:}

1. Insoo Kim Berg and Norm Reuss. Solutions Step-by-Step. WW Norton, 1997. 192 p.

2. Батанов О.В. Територіальна громада-первинний суб'єкт муніципальної влади в Україні: поняття та ознаки. Вісник Центральної виборчої комісії. 2008. № 2 (12). С. 51-57.

3. Березинський В. П. Самоорганізаційний потенціал громади у децентралізаційних процесах у сучасній Україні. Вісник Дніпропетровського універcumemy. 2017. № 1 (23). C. 77-84.

4. Більшість українців виступають за продовження реформи децентралізації, - опитування. URL: https://lb.ua/news/2020/01/30/448537_bolshinstvo_ ukraintsev_vistupayut.html.

5. Кирилюк В.В. Сучасні підходи щодо визначення рівня соціальної згуртованості. Соціально-трудові відносини: теорія та практика. 2014. № 1. C. 384-389. 


\section{ГАБІТУС}

6. Майже $60 \%$ українців переконані, що децентралізація потрібна, - результати дослідження. URL: https://decentralization.gov.ua/news/10716.

7. Методика малюнкової фрустрації (С. Розенцвейга). Практикум з психології : навчальний посібник. Київ : МАУП, 2007. С. 273-298.

8. Мороз О.Ю. Територіальна громада: сутність становлення та сучасні українські реалії. Демократичне врядування. 2008. Вип. 2. URL: http://lvivacademy.com/vidavnitstvo_1/visnik2/fail/ Moroz.pdf.

9. Особливості впровадження ресорми децентралізації в Запорізькій області: результати соціо- логічного дослідження. Березень 2017 року. URL: https://decentralization.gov.ua/pics/upload/796-6be3e2 6581d4de687419a0d3d49b3728.pdf.

10. Про місцеве самоврядування в Україні : Закон України. Відомості Верховної Ради України (BВP). 1997. № 24. Ст. 170.

11. Про органи самоорганізації населення : Закон України. Відомості Верховної Ради України (BВР). 2001. № 48. Ст. 254.

12. Успішна територіальна громада: будуємо разом / М. Бриль, О. Врублевський, О. Данчева, А. Сеїтосманов, Е. Чубаров. Харків : Видавничий будинок «Фактор», 2018. 128 c. 